\title{
Effect of Rebranding and Repositioning On Brand Equity Considering Brand Loyalty as a Mediating Variable
}

\author{
Sundus Zahid, Ms. Naintara Sarfaraz Raja \\ Foundation University Rawalpindi Campus \\ Foundation University Rawalpindi Campus
}

\begin{abstract}
In this research paper the researcher discusses the effect of rebranding and reposition on brand loyalty that impacts brand equity in case of Mobilink Pakistan. The researchers has selected rebranding and repositioning as independent variables, brand loyalty as mediating variable and brand equity as dependent variable. The study is done from twin cities of Pakistan "Islamabad and Rawalpindi". Data has been collected through questionnaires. Hypotheses are built and significant of each variable is tested, correlation and regression are used on Spss. Analysis are done on the basis of Spss. The result shows that brand loyalty doesn't mediate the relation in case of researcher's study. For future researches more variable should be discussed and a larger sample size should be taken from different cities.
\end{abstract}

\section{Introduction}

Important brand elements include the name, logo, and slogan. These are considered to be vital organs of every brand name; and if a company decides to change any of these, it is important to make the change have an impact that the consumers would remember, recognize, and can associate with. The change should be able to make the consumers recall the brand name (AlShebil 2007). With rapid developments and changes in the consumer behavior, the need for outlining rebranding and repositioning strategies arose widely. It gave companies a competitive edge as well. Visual elements of the brand are redefined in an attempt to reposition the brand as a whole. Usually, the logo, color, and taglines are changed or improved.

When a company rebrands or repositions itself, it has to consider factors that are affecting the company. Brand equity, i-e importance of your brand, how rebranding and repositioning is affecting your brand equity; the image and the importance that your brand gives to people.

Another important factor is brand loyalty that is willingness of your customers to go for your brand. Considering how rebranding and repositioning is affecting your brand loyalty, the affect can be positive or negative depending on your marketing strategies and also evaluating how loyalty is affecting brand equity. The higher the brand equity or perceptive association, the more favorable will be the customer's response towards the promotional efforts of the brand.

\section{Background of the Study}

Rebranding is all about creating new image and position in consumer's mind and establishing a new name, slogan, tagline or design (Muzellec and Lambkin 2006). To maintain brand and customer loyalty, rebranding has become one of the important strategies to be successful and to attain brand values. Marketers consider rebranding as an effective way to restore the obsolete brand and considering rebranding the solution to face market challenges(Petburikul 2009).

Repositioning is a source of competitive advantage that gives value to customers at different stages of marketing and at different contact points (Lindberg-Repo, 2005:80). According to Keller (2008:98) repositioning is done for changing the image of the company so that it occupies a new place and value in the mind of the consumers.

Brand loyalty leads to band equity (aaker 1991). According to Aaker (1991) even when you have small loyal customer base it can make a positive significant change in your brand equity.

Brand equity is that power which lies in what consumers have seen, learned, heard and felt so far by that particular brand which they have gauged through experience (Keller 1998). Factors that gives positive or negative value to the brand is a collection of various variables that can be brand awareness, brand perception, brand loyalty and the association that they have with that particular brand (Aaker, 1991

\section{Importance of the Study:}

There are many companies that rebranded and repositioned completely or changed some of its elements. The reasons for rebranding and repositioning vary from company to company, some might want to get greater market share and some want to rebrand because there might be difference in what they wanted and what they have right now. 
Many companies are going towards rebranding and repositioning that depends on the demand of the market and also because to acquire the latest marketing strategy according to their customers. (Spaeth 2005).

Pakistan telecommunication company MOBILINK has recently rebranded itself. It has changed its logo, tagline, and color and target market.

The importance of rebranding is that it doesn't involve much cost and can be done within allotted budget. A factor that is usually not considered while rebranding is the impact that it left on customers after rebranding. In this research paper the researcher will be studying affects of rebranding and repositioning on customers in the form of brand loyalty and the importance they give to MOBILINK.

\section{Purpose of the Study:}

In the following paper, researcher will be examining a recent rebranding "MOBILINK Pakistan" in Telecom sector. Following factors including customer's perception about new logo, design advertisement and target market will be studied. As Mobilink has recently rebranded so there has been no study done on it especially with customer's perception.

Two dimensions from customer point of view will be studied. First is that how brand loyalty is affecting rebranding and repositioning. Second, by rebranding and repositioning MOBILINK do consumers really valuing this brand and are they still considering this brand important or not.

\section{Aims and Objectives}

Following are the aims and objectives of the research:

- To identify the affects of rebranding and repositioning on consumer loyalty.

- To identify the impact or rebranding and repositioning on brand equity.

- To identify the impact of brand loyalty on brand equity.

\section{Literature Review}

Rebranding:

Rebranding has two dimensions that are evolutionary and revolutionary. Evolutionary rebranding defines minor changes in product or brand positioning while revolutionary reflect major change in brand's positioning, usually in the form of design name or logo (Muzellec and Lambkin , 2006). Rebranding can be proactive or reactive. Proactive rebranding occurs when companies wants to grasp future opportunities and productive growth while reactive rebranding occurs in reaction to events (Susan Gunelius, 2013). Koku (1997) describes several reasons for rebranding. He says that more companies are now going for rebranding and the reasons can be merger and acquisition, new line of business or to attain more competitive advantages. Goi and Goi(2011) said that rebranding makes a totally new image of the product and old identity is usually forgotten.

\section{Repositioning:}

Rosenthal (2003) says repositioning is different from rebranding because reposition is done in consumer's mind, in repositioning brand is not changed but image of that brand changes in consumer's perception. When there is change in consumer demand and products then repositioning is the best strategy for the companies to position themselves again in the market. Studies have shown the reaction of people against repositioning that they react when a company's reposition itself again (Terse Norlander, 2007). The reason for rebranding can also be that if the customers are considering the brand boring and they are lacking interest in that brand even though there are different integrated marketing communications but it reduces the power to convey its message to their potential customers, then in this situation repositioning need to be done in order to attain customers and to find a new and improved identity in the market (Anja H. Bjorkdhal, 2004).

\section{Brand loyalty:}

The behavioral component is linked to purchase loyalty or the frequency of purchase, and favorable attitude towards a brand with respect to its competition is the attitudinal component (Sheth and Mittal, 2004. Strategic marketing efforts are all planned on the basis of customer loyalty towards the brand (Kotler. 1994). Brand loyalty of the target market makes a business entity stronger and enables it to attain greater market share. The previous practice of attempting to steal customers from competitive brands has now changed. Efforts are now focused on retaining existing customers of a brand and devising plans to not let them switch to some other fancy offer (Kapferer, 1992). Brand loyalty is a person's decision to purchase and repurchase a brand's product on a regular basis, consciously or unconsciously (Wolfe and Ferland). Brand loyalty is the measure of how strongly one brand is preferred in comparison to other brands offering the same product or service, based on price sensitivity and frequency of purchase (brandchannel.com, 2006). 


\section{Brand Equity}

Business practices, academically conducted research, and brand management as a whole, contain a significant component known as brand equity (Kim et al. 2006). A structural framework developed by Aaker (1991) suggests that brand equity creates value for the business and the customer both; as the value for the customer increases, the value for the firm increases simultaneously; and that brand equity comprises of various dimensions. Brand equity enables a business to differentiate its products in order to gain a competitive edge, hence increasing cash inflows (Yoo et al 2000; Aaker, 1991). As Aaker puts it, positive brand equity affects the firm positively in the long-term. According to Keller (2002), strong brand equity improves the perceptions related to the performance of a certain product, increases customer loyalty towards the brand as a whole, makes a brand less vulnerable to competitions' marketing strategies and a crisis in the industry of business, enables chances of greater margins, creates an inelastic market response towards an increase in prices, gives way to improved trading and global support, increases the effectiveness of marketing efforts, and brings in licensing and extension opportunities for the business.

\section{Overview}

\section{Research Methodology}

In this section the researcher defines the research methodology. TELECOMMUNICATION SECTOR "MOBILINK" has recently done rebranding and has repositioned itself, the researcher is concerned about consumer's response towards this rebranding. MOBILINK Pakistan has rebranded so wonderfully and has engaged its customers in almost all activities. This has been Pakistan's most identifiable rebranding that has been done yet.

\section{Sample Size and Population}

This study is based on the population of the twin cities of Pakistan. . The unit of analysis in this study is the customers of MOBILINK and other network users. The study which the researcher is conducting is mainly from the citizens of Islamabad and Rawalpindi. The sample size will be between 225-250 respondents. Nonprobability convenience sampling will be done from the twin cities of Pakistan.

\section{Data Collection Method}

Questionnaires are used to collect the quantitative data. Questionnaires have two sections: the personal data and the research questions. The questionnaires are developed on the basis of independent and dependent variables. The scale for measuring the impact is 5 point likert scale. The sample size is between 225-250 respondents.

\section{Analysis}

Analysis will be done by using SPSS. To direction variables correlation and regression will be used. Reliability test will also be conducted to support the research in the form of data reliability. For moderating variable moderating test will be used.

\section{Limitations:}

Following are the limitations that will be faced to carry out this research paper.

- Few variables are being discussed in this paper but more independent and dependant variables can also be studied.

- Due to limited time and financial constraints data from two cities is analyzed, for future researchers more cities should be considered.

\section{The Research Process}

In this research paper the researcher wants to study four variables that are:

- rebranding as independent variable

- repositioning as independent variable

- brand loyalty as mediating variable

- brand equity as dependant variable

\section{Theoretical Framework}

The following theoretical framework further explains this relationship: 


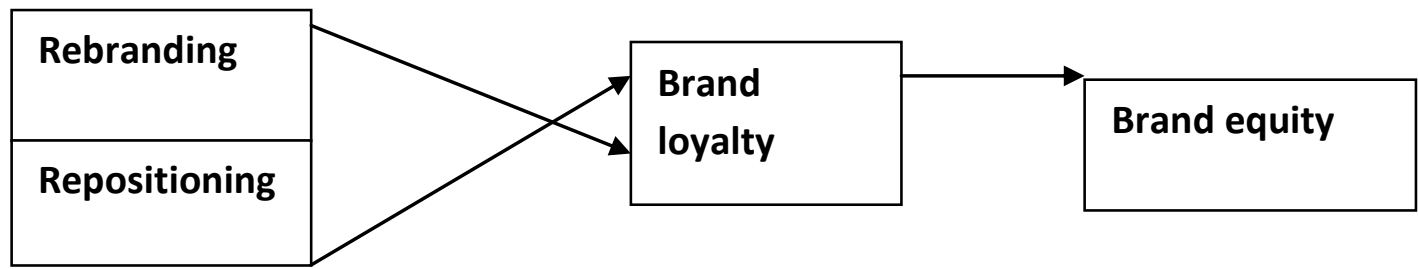

(FIGURE 1)

Hypotheses:

Following are the hypotheses that are developed.

- H1: rebranding has a significant relation with brand loyalty

- H2: rebranding has a significant relation with brand equity

- H3: repositioning has a significant relation with brand loyalty

- H4: repositioning has a significant relation with brand equity

- H5: brand loyalty has a significant relation with brand equity

- H6: impact of rebranding and repositioning on brand loyalty

- H7: impact of rebranding and repositioning on brand equity

\section{Data Analysis:}

SPSS RESULTS: Correlation and regression test will be used.

\section{CORELATION:}

The following tables shows correlation between rebranding, repositioning, brand loyalty and brand equity

\begin{tabular}{|c|c|c|c|c|c|}
\hline \multicolumn{6}{|c|}{ Correlations } \\
\hline & & Rebranding & Repositioning & BrandLoyalty & BrandEquity \\
\hline \multirow[t]{3}{*}{ Rebranding } & Pearson Correlation & 1 & .874 & $.946^{\prime \prime}$ & $.995^{\prime \prime}$ \\
\hline & Sig. (2-tailed) & & .000 & .000 & .000 \\
\hline & N & 240 & 240 & 240 & 240 \\
\hline \multirow[t]{3}{*}{ Repositioning } & Pearson Correlation & $.874^{\prime \prime}$ & 1 & $.879^{\prime \prime}$ & $.870^{\prime \prime}$ \\
\hline & Sig. (2-tailed) & .000 & & .000 & .000 \\
\hline & $N$ & 240 & 240 & 240 & 240 \\
\hline \multirow[t]{3}{*}{ BrandLoyalty } & Pearson Correlation & $946^{\prime \prime}$ & $879^{\prime \prime}$ & 1 & $943^{\prime \prime}$ \\
\hline & Sig. (2-tailed) & .000 & .000 & & .000 \\
\hline & N & 240 & 240 & 240 & 240 \\
\hline \multirow[t]{3}{*}{ BrandEquity } & Pearson Correlation & $.995^{\prime \prime}$ & $870^{\circ}$ & $.943^{\prime \prime}$ & 1 \\
\hline & Sig. (2-tailed) & .000 & .000 & .000 & \\
\hline & N & 240 & 240 & 240 & 240 \\
\hline
\end{tabular}

(TABLE 1)

The above table shows correlation among four variables. All these variables are significant with each result; sig (2-tailed) is less than 0.005 . This table verifies our following hypotheses.

- H1: rebranding has a significant relation with brand loyalty

- H2: rebranding has a significant relation with brand equity

- H3: repositioning has a significant relation with brand loyalty

- H4: repositioning has a significant relation with brand equity

- H5: brand loyalty has a significant relation with brand equity

REGRESSION:

To run mediation, regression test will be used. Relation among the following hypotheses will be tested.

- H6: impact of rebranding and repositioning on brand loyalty

For H6:

- H7: impact of rebranding and repositioning on brand equity 


\begin{tabular}{|c|c|c|c|c|c|c|}
\hline \multicolumn{7}{|c|}{ Coefficients ${ }^{3}$} \\
\hline \multirow{2}{*}{\multicolumn{2}{|c|}{ Model }} & \multicolumn{2}{|c|}{ Unstandardized Coefficients } & \multirow{2}{*}{$\begin{array}{c}\begin{array}{c}\text { Standardized } \\
\text { Coefficients }\end{array} \\
\text { Beta }\end{array}$} & \multirow[b]{2}{*}{$\mathrm{t}$} & \multirow[b]{2}{*}{ Siq. } \\
\hline & & $\mathrm{B}$ & Std. Error & & & \\
\hline \multirow[t]{3}{*}{1} & (Constant) & .035 & .080 & & .444 & .658 \\
\hline & Rebranding & .787 & .043 & .752 & 18.484 & .000 \\
\hline & Repositioning & .220 & .040 & .222 & 5.448 & .000 \\
\hline
\end{tabular}

(TABLE 2)

The above table shows significant level 0.658 that is greater than 0.005 so there is no significant relation between them and this disproof's our H6.

For H7:

- H6: impact of rebranding and repositioning on brand loyalty

\begin{tabular}{|c|c|c|c|c|c|c|}
\hline \multicolumn{7}{|c|}{ Coefficients ${ }^{s}$} \\
\hline & & \multicolumn{2}{|c|}{ Unstandardized Coefficients } & \multirow{2}{*}{$\begin{array}{c}\begin{array}{c}\text { Standardized } \\
\text { Coefficients }\end{array} \\
\text { Beta } \\
\end{array}$} & \multirow[b]{2}{*}{$t$} & \multirow[b]{2}{*}{ Sig. } \\
\hline & & $\mathrm{B}$ & Std. Error & & & \\
\hline & (Constant) & .010 & .026 & & 403 & .687 \\
\hline & Rebranding & .994 & .014 & .993 & 71.612 & .000 \\
\hline & Repositioning & .002 & .013 & .002 & .132 & .895 \\
\hline
\end{tabular}

(TABLE 3)

Table 3 shows insignificant result 0.687 and there exist no relations between variables and this disproof's our H7:

\section{- H7: impact of rebranding and repositioning on brand equity}

ANALYSIS:

Table 1 shows correlation among four variables and proofs our following hypotheses: H1, H2, H3, H4 and H5. The results show that there is a significant relation between these four variables. Table 2 and 3 shows results for mediation. Both tables show insignificant results which reject our H6 and H7. Table 2 shows that there is no mediation in the relationship. Brand loyalty is not showing any mediation with rebranding and repositioning. Similarly table 3 is also showing insignificant results.

\section{Conclusion:}

In case of rebranding and repositioning of Mobilink Pakistan, brand loyalty is not acting as a mediating variable. Result shows that brand loyalty is not affected by rebranding and repositioning nor it is transferring its affect on brand equity. The reason behind this result can be the fact that MOBILINK PAKISTAN has recently rebranded itself and people might not be much familiar with this rebranding and repositioning so future research should be done on it after some long time. More researches should be done on this relationship. The reason for these results might be the fact that limited areas were selected by researcher for this research. For further details and in-depth knowledge more areas should be selected for research. Due to financial and cost constraints geographical areas were limited to two cities only, so for future researches more geographical areas should be considered.

In this research paper researcher selected four variables for this study, so for future studies other variables should also be linked with this relation.

\section{References:}

[1]. Aaker, D. A. "Managing Brand Equity: Capitalizing on the value of a Brand Name." The Free Press, New York, 1991.

[2]. Aaker, D. A. 1991. Managing brand equity capitalizing on the value of a brand name; managing brand equity capitalizing on the value of a brand name. New York: Free Press.

[3]. Bloemer, J. M. M. and Kasper, H. D. P. (1995) The Complex Relationship between Consumer Satisfaction and Brand Loyalty. Journal of Economic Psychology, 16, 311-329

[4]. Brandchannel.com (2006) (http://www.brandchannel.com), Accessed 18 August 2006.

[5]. Goi, C, L.,, and T, M., Goi. "Review on Models and Reasons of Rebranding." International Conference on Social Seiences and Humanity, 2011.

[6]. Kapferer, Jean-Noël.(1992). Strategic Brand Management. New York: The Free Press.

[7]. Keller, K. L. "Managing Brand for longrun : Brand reinforcement and revitalization strategy." California Management Review, 1999: 102-24.

[8]. Keller, K. L. (2002). Branding and brand equity. Cambridge, MA: Marketing Science Institute 
[9]. Keller, K. L. Strategic Brand Mnangement. Prentice Hall, Upper Saddle River, 2003.

[10]. Keller, K. L., "Conceptualizing, Measuring and managing customer-based brand equity." Journal of Marketing, 1993: 1-22

[11]. Koku, P.S.,. "The Impact of Strategic Name Change on Student Enrollment In Colleges and Universities "Journal of Markering for Higher Education, 1997: 53-71.

[12]. Kotler, P. and Keller, K, L. (2006) Marketing management. 12th edition, Pearson education,Inc., Upper saddle river, New Jersey.

[13]. Muzellec, L. and Lambkin, M. "Corporate rebranding: Destroying, transfering or creating brand equity." European Journal of Marketing, 2006: 803-824.

[14]. Petburikul, K.,. "The Impact of Crporate Rebranding of West Viginia Higher Education." RU International Journal, 2009.

[15]. Rosenthal, G.,. "A name by another name: Responding to increasing role of marketing in higher education." Doctoral Dissertation, University of Pennsylvania, 2003.

[16]. Sheth, J. N., \& Mittal, B. (2004). Customer behavior: a managerial perspective. Thomson.

[17]. Spaet, T.,. "Rebranded and Reborn, Across the Brand." 2005: 18-23.

[18]. Susan, G.,. AYTM BLOGS. 2013. http://aytm.com/blog/research-junction/rebranding-essentials-why-rebrand/ (accessed February Wednesday, 2013).

[19]. Wernerfelt, Birger (1988), "Umbrella Branding as a Signal of New Product Quality: an Example of Signaling by Posting a Bond," RAND Journal of Economics, 19(3), 458-466.

[20]. Wolfe, Kent; Ferland, Christopher. (No date). Creating a brand.The University of Georgia.Working paper, 12556.

[21]. Yoo,B., Donthu, N., and Lee, S., (2000) An Examination of Selected Marketing Mix Elements and Brand Equity. Journal of the Academy of Marketing Science, 28 (2): 195-211.

[22]. Zeithaml, V.A., Berry, L.L. and Prasuraman, A. "The Behavioral Consequences of Service Quality." Journal of Maeketing, 1996: 31-46. 